\title{
Government Sponsored Advertisements: Do They Cultivate Higher Order Thinking Skills?
}

\author{
Dr Saroja Dhanapal ${ }^{1}$, Sharmaine Sakthi Anantha ${ }^{2}$, Riaz Fathima Binti Omar Farouk ${ }^{3}$ \\ ${ }^{1}$ Faculty of Business and Law, Taylors University \\ saroja.dhanapal@taylors.edu.my \\ ${ }^{2}$ Faculty of Business and Management, Asia Pasific University \\ sharmaine@apu.edu \\ ${ }^{3}$ Faculty of Business and Management, Asia Pasific University
}

riaz@apu.edu.my

\begin{abstract}
Advertising can be defined as an openly sponsored offering of goods, services, or ideas through any medium of public communication. Advertising, in the past decade has undergone significant development and it now comprises television, radio and internet besides the traditional print media. Levens (2012) defines advertising as the paid, non-personal communication of a marketing message by an identified sponsor through mass media which acts as a tool for a company to massively introduce a product or service to the consumers using the available media that are endless starting from billboards, posters, wall paintings to the most explicit places like the back of event tickets or even the public transport that roams all over the city. Government sponsored advertisements (GSA) or public service advertisement (PSA) on the other hand can be defined as messages in the public interest disseminated by the media without charge. Today, public service advertising has been increasingly used in a non-commercial fashion in several countries across the world in order to promote various social causes (Devadas and Manohar, 2011). The objective is to raise awareness, change public attitudes and behavior towards social issues. The purpose of this paper is to explore as to whether advertisements sponsored by the Malaysian government merely disclose social responsibility information or do they go beyond this to inculcate Higher Order Thinking Skills among the audience from the three generations; Baby boomers, Generation $X$ and Generation Y. As such, a purposive sampling was used in the selection of the advertisements for the study based on the content that catered for the three generations. To identify whether the advertisements inculcate Higher Order Thinking Skills (HOTS) according to Bloom's Taxanomy (1990), the contents of the advertisements were analysed using a framework based on an integrated approach combining content and semiotic analysis. To further support the findings, a survey was carried out among 100 samples to identify their perception on government sponsored advertisements. The samples for the survey were also selected using a purposive sampling. This was to ensure that there were representatives from the three generations. It is hoped that this study will contribute to the scarce literature on the effectiveness of advertisements in cultivating Higher Order Thinking Skills.
\end{abstract}

\section{Indexing terms/Keywords}

Government Sponsored Advertisements, Higher Order Thinking Skills and Integrated Approach

\section{Academic Discipline And Sub-Disciplines}

Marketing

SUBJECT CLASSIFICATION

Advertising

\section{TYPE (METHOD/APPROACH)}

Qualitative Research Method

\section{Council for Innovative Research}

Peer Review Research Publishing System

Journal: International Journal of Management \& Information Technology

Vol. 5, No. 2

editor@cirworld.com

www.cirworld.com, member.cirworld.com 


\section{INTRODUCTION}

Advertising is a huge industry, which imposes great expense on manufacturers and service providers. In accordance with Curtis (2011), advertising is a form of communication to convince or persuade the audience and affect them in the decision making process in regards to a particular product or service. At its inception, advertising was merely an announcement; for example, entrepreneurs in ancient Egypt used criers to announce ship and cargo arrivals which developed further with the invention of printing, which is said to have ushered in modern advertising (Anderson et al., 2009). Commercial advertising is sometimes defined as a form of "information" and an advertiser as "one who gives information" where the ultimate aim is to promote a product or service. Unlike traditional commercials, government sponsored advertisements (GSA) or public service advertisements (PSA) are primarily designed to inform and educate rather than sell a product or service and the goal is not to make a big sale, but rather to change public opinion and raise awareness of a problem (Suggett, 2010). The implication is that the defining function of GSA or PSA is to provide information to the public. Among the relevant and important information disseminated are such as social matters and social welfare causes like AIDS, energy conservation, political integrity, deforestation, illiteracy, poverty and so forth (Devadas and Manohar, 2011). It must be noted that the productivity and contribution of advertising research during the past forty years is impressive. It has revealed much about human behaviour and the influence of communication. This research aims to evaluate GSA in Malaysia in relation to the cultivation of Higher Order Thinking Skills (HOTS). Research has been limited in studies regarding GSA (Mohd Helmi et al., 2012), especially in developing countries such as in Malaysia where the level of awareness is still at its infancy. There is also a lack of research on GSA, in terms of the perception or attitude to cultivation of Higher Order Thinking Skills (Mohd Helmi et al., 2012). This study, therefore, provides a much needed insight into the implications of governmental advertisements. It hopes to contribute towards the effectiveness of future advertisements. Thus, the primary goal of this study is to assess the level of awareness and perceptions of Malaysians within the three generations (Baby boomers, Generation X and Generation $Y$ ) towards advertising campaigns by the government. Further, it aims to evaluate the effectiveness of advertising as a platform to cultivate Higher Order Thinking Skills among the three generations. The result of this article will contribute in terms of improving 'message delivery' and the effectiveness of advertising to the targeted groups.

\section{LITERATURE REVIEW}

The definition of critical thinking has changed somewhat over the past decade. The subject was originally dominated by the cognitive psychologist and philosophers, but behaviorally-oriented psychologist and content specialists have recently joined the discussion. Mertes (1991) defines it as a conscious and deliberate process which is used to interpret or evaluate information and experiences with a set of reflective attitudes and abilities that guide thoughtful beliefs and actions. Mayer and Godchild (1990) on the other hand define critical thinking as an active, systematic process of understanding and evaluating arguments. An argument provides an assertion about the properties of some object or the relationship between two or more objects and evidence to support or refute the assertion. Critical thinkers acknowledge that there is no single correct way to understand and evaluate arguments and that all attempts are not necessarily successful.

In the past, researches have demonstrated that television public service announcements (PSAs) designed for and targeted to specific teen personality-types have been very effective. This is evidenced in the significant reduction in the use of marijuana where researchers found that PSAs with an anti-marijuana use message resulted in at least a 26.7 percent drop in the use of that drug among the targeted teen population (NIDA, 2001). According to Leshner et all, public health messages can have a significant impact if they are prepared and delivered appropriately (cited in NIDA, 2001). This is further supported by Jorgens who said that the intelligence, sensitivity, and imagination reflected in that 30 or 60 seconds does much to influence the public perception of the sponsoring organization, and the importance of the issue (cited in NIDA, 2001). Although there are evidences to show the effectiveness of PSAs, there are also evidences to show how PSAs have failed in their attempts to create awareness and change attitudes of the public. According to Wooden (1997), PSAs falter for a number of reasons: lack of impact, relevance, courage or clarity, from wallowing in the problem rather than steering the public towards a solution and, of course, too little media. In the analysis of strategies adopted in PSAs, researchers have identified a number of common strategies among which are "help-self" PSAs (Guy and Patton, 1988) and fear appeals as motivators to get people to help them (McDaniel and Zeithaml 1984; Ray and Wilkie 1970; Spence and Moinpour 1972; Sternthal and Craig 1974; Tanner, Day, and Crask 1989). Tanner, Hunt, and Eppright (1991) have identified a new strategy where the protection motivation model borrowed from psychology can be adapted to predict people's intentions to act in a manner required. In the use of the fear appeal strategy, fright and anxiety is created in the target audience. This is done by cultivating a sense of personal danger on the audience while in the protection model strategy, the goal is to motivate people to help others in danger; the appeal is thus indirect.

\section{THEORETICAL FRAMEWORK}

Approaches to analyzing advertisements include textual analysis, semiotics, rhetorical analysis, discourse analysis and 'content analysis'. In the media of advertising, both semiotics and content analysis are commonly used. Semiotics is the study of signs and how they are mediated by the reader. All advertising is comprised of a combination of signs or what Ferdinand de Saussure, the father of semiotics, called syntagmatic relations (cited in Culler, 1986:59-62). According to Ross (1993), semiotics, applied to advertising, is an attempt to construct meaning from both verbal and non-verbal signs through understanding and interpretation. According to Williamson (1990:12), as a tool for examining advertising, semiotics helps us understand how signs and symbols are manipulated to form "structures of meaning". Content analysis focuses on explicit content and tends to suggest that this represents a single, fixed meaning. Further, whilst content 
analysis involves a quantitative approach to the analysis of the manifest 'content' of media texts, semiotics seeks to analyse media texts as structured wholes and investigates latent, connotative meanings. However, some researchers have combined semiotic analysis and content analysis (Glasgow University Media Group 1980; Leiss et al., 1990; McQuarrie \& Mick, 1992). There is voluminous research on advertising language, particularly of interest to the advertising industry (Langrehr, 2003); yet the focus there tends to be on the products and consumers' feedback, with research findings applied to improve marketing strategies for commercial ends. This study, by contrast, is oriented to evaluating GSAs in relation to cultivating HOTS and to do so, the researchers would be using an integrated approach which combines both content analysis and semiotics.

Semiotics is an area of study which is abstract due to the different theoretical stances and methodological tools used. Researchers have concluded that semiotics involves both signs noted in everyday speech as well as the connotative meanings that these signs represent. As such, signs comprise of words, images, sounds, gestures and objects. Whilst for the linguist Saussure, 'semiology' was 'a science which studies the role of signs as part of social life', for the philosopher Peirce, 'semiotic' was the 'formal doctrine of signs' which was closely related to logic (Peirce, 1931-58: 227). Semiotics can be said to be part of linguistics especially the study of semantics, however Sturrock (1986: 222) argues that semantics focuses on what words mean while semiotics is concerned with what signs mean. On the other hand, Morris (1938) claims that semiotics embraces semantics. For the purpose of this study, semiotics is taken to encompass semantics. With regards to content analysis, researchers have defined it as a systematic, replicable technique for compressing many words or texts into fewer content categories based on explicit rules of coding (Berelson, 1952; GAO, 1996; Krippendorff, 1980; and Weber, 1990). Content analysis can also be broadly defined as "any technique for marking inferences by objectively and systematically identifying specific characteristics of messages" (Holsti, 1969: 14).

\section{METHODOLOGY}

This research adopted a qualitative research method where an integrated approach comprising content analysis and semiotic analysis was used to analyse the advertisements. To support these findings, a survey was conducted among 120 samples from the three generations. For the purpose of analyzing the contents of the advertisements, the theoretical framework in Figure 2 was adopted.

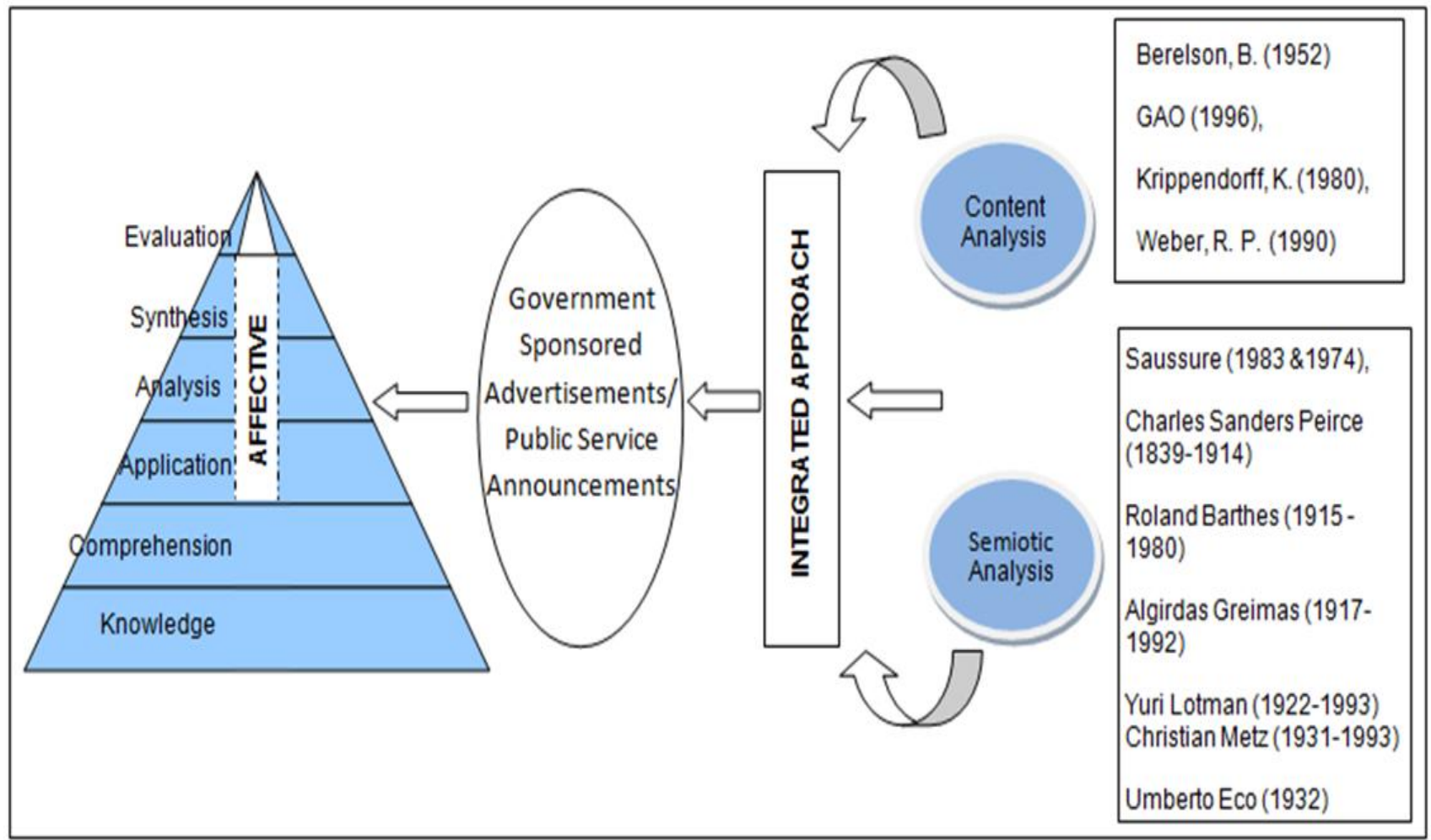

Fig 1: Integrated Approach

The integrated approach shown in Figure 2 combines the content and semiotic analysis. In terms of the content analysis, the researchers analysed the contents of the messages in the advertisements to identify both denotative and connotative meanings. With regards to the semiotic analysis, features such as the words used, gestures, facial expressions, images, objects and the concluding captions were tabulated and analysed. The analysis focused on the extent to which the advertisements inculcated Higher Order Thinking Skills as projected in Bloom's Taxonomy. The researchers, however, have altered the Bloom's Taxonomy by including the affective domain which is shown to be in existence more with the Higher Order Thinking Skills starting from the application level. The reason for the researchers' placing of affective domain as existing from the application domain is based on Rosenblatt's (1978) claim that there are two stances to the reading of literary texts. The difference between the two stances is that efferent reading requires learners to identify meaning while 
aesthetic reading requires reactions to the meaning being constructed (Rosenblatt, 1994). At the knowledge and comprehension level, there is more efferent reading while from the application level onwards; there is aesthetic reading which requires learners to react to the texts. The researchers consider the affective domain to be on the same line as the aesthetic reading for it involves stirring of personal feelings, ideas and attitudes that lead to new experiences and this is applicable to all kinds of texts including advertisements. Rosenblatt (1985) asserts further that the aesthetic stance involves a transition between the reader and the text as the reader crosses over and enters into the world of the text to experience the story, events. Here, the researchers are of the opinion that this relationship can be extended to the audience and the advertisements. At the knowledge and comprehension levels, there is mere understanding with no focus on personal feelings. The researchers have adopted this adapted version of Bloom's Taxonomy to analyse the advertisements selected

The sampling procedure can be considered as the most important element in a survey. For the purpose of this paper, the researchers adopted a purposive sampling as it was hoped that the responses obtained from the different age groups (Baby boomers, Generation X and Generation $Y$ ) will be more accurate and reliable in analyzing whether government sponsored advertisements catered to Higher Order Thinking Skills. For the selection of the advertisement, the researchers used a combination of convenience and purposive sampling. The researchers chose the most current and easily accessible advertisements aired over the television but at the same time focus was given to the contents which were relevant to the three generations.

In addition, a survey questionnaire was designed with the sole intention of seeking information as to the impact of government sponsored advertisements on the public in relation to the cultivation of the Higher Order Thinking Skills. This is to support the findings from the content and semiotic analysis. A total of 22 questions were constructed and among the key demographic questions was the age group of samples (Baby boomers, Generation X and Generation $Y$ ). This question was highly essential as it gave the researchers information as to how government sponsored advertisements had different kinds of impact on these generations.

\section{FINDINGS AND DISCUSSIONS}

Four television advertisements were selected for the study. The selection was based on the contents of the advertisements. An analysis of the advertisements was done using the integrated approach incorporating the content and semiotics analysis approach. Table 1 shows the detailed tabulation of the content of the 4 (four) GSAs that were selected for the study.

Table 1: Tabulation of Information on Selected Advertisements

\begin{tabular}{|l|l|l|l|l|l|}
\hline No. & Theme & Source & Time & Main Character & Minor Character \\
\hline Adv. 1 & Smoking & TV & 3.02 & $\begin{array}{l}\text { Smokers } \\
\text { Family }\end{array}$ & Hospital children \\
\hline Adv. 2 & AIDS & TV & 1.00 & $\begin{array}{l}\text { Prostitute } \\
\text { Drug addict } \\
\text { Family }\end{array}$ & $\begin{array}{l}\text { Hospital } \\
\text { Public } \\
\text { Night club } \\
\text { Scientist }\end{array}$ \\
\hline Adv. 3 & Bribery & TV & 0.53 & $\begin{array}{l}\text { Father } \\
\text { Mother } \\
\text { Elder Brother } \\
\text { Younger Sister }\end{array}$ & Nil \\
\hline Adv. 4 & $\begin{array}{l}\text { Don't } \\
\text { Drink } \\
\text { and } \\
\text { Drive }\end{array}$ & TV & 1.04 & $\begin{array}{l}\text { Nurse } \\
\text { Doctor } \\
\text { Drunk Driver } \\
\text { Victim } \\
\text { Parents } \\
\text { Surgeon }\end{array}$ & $\begin{array}{l}\text { Hospital } \\
\text { Attendants } \\
\text { Nurses } \\
\text { Police Officer }\end{array}$ \\
\hline
\end{tabular}

Table 1 shows the tabulation of the general features of the 4 advertisements selected. Advertisement 1 which is on smoking comprises of 3 short scenes involving three families from the three main ethnic groups in Malaysia. It is the longest advertisement lasting for 3.02 minutes. Advertisement 2 is on drug addiction. The scenes are set in 3 different locations unlike Advertisement 1 where the whole scene was shot in the hospital. The setting for Advertisement 2 is the hospital, public spots and a night club. The advertisement lasts for 1:00 minute and has a number of characters. The advertisement depicts a few prostitutes, drug addicts and family members. Advertisement 3 is on bribery. This advertisement is the shortest of the four and it lasts for 53 seconds. The scene is limited to a home and a single family consisting of the father, mother, son and a daughter. Advertisement 4 is on "Don't drink and drive". Its duration is almost similar with advertisement 2 where it lasts for 1.04 minutes. The number of characters portrayed is large. Among these would be the drunk driver, victim, victim's parents and the doctors. The whole scene is set in the hospital. On the whole, an initial analysis of the advertisements indicates that they have been designed to capture not only the awareness of the social problems portrayed but also to cultivate Higher Order Thinking Skills of the audience. This will be discussed further in accordance with the respective advertisements. Table 2 give an in depth analysis of Advertisement 1. 
Table 2: Analysis of Advertisement 1 (Smoking)

\begin{tabular}{|c|c|}
\hline Content Analysis & Semiotic Analysis \\
\hline $\begin{array}{l}\text { Scene 1: Pregnant wife and husband - where husband } \\
\text { is having breathing difficulties and appears to be at the } \\
\text { deathbed. (Malay family) }\end{array}$ & $\begin{array}{l}\text { Words: Husband's remorseful words "Forgive me", } \\
\text { "forgive daddy" (repetition) } \\
\text { Images: Amputation, portrayal of difficulty in breathing and } \\
\text { connotative idea that the wife is pregnant } \\
\text { Objects: surgical instruments } \\
\text { Gesture/Facial expression: the nurse's understanding look } \\
\text { that is reciprocated by the wife }\end{array}$ \\
\hline $\begin{array}{l}\text { Scene 2: Mother, son and grandfather - where the } \\
\text { mother suffering from mouth gangrene. Son is reluctant } \\
\text { to go near her. (Chinese family) }\end{array}$ & $\begin{array}{l}\text { Words: mother's heartfelt cry for the son to come near, } \\
\text { grandfather's interpretation to the grandson "mommy's } \\
\text { calling" } \\
\text { Images: Portrayal of the mother's face with a vivid } \\
\text { projection of the mouth with severe gangrene, mother's } \\
\text { sobbing and son turning away from the mother } \\
\text { Objects: Birthday card to the son } \\
\text { Gesture/Facial expression: nurse's tap on the mother's } \\
\text { shoulder, son's nodding }\end{array}$ \\
\hline $\begin{array}{l}\text { Scene 3: Husband and wife - where the husb } \\
\text { has been amputated. (Indian family) }\end{array}$ & $\begin{array}{l}\text { Words: Husband's painful utterance "My leg is gone...It's } \\
\text { gone... all is gone", wife's consoling words "Yes, but you } \\
\text { are alive. We are lucky." } \\
\text { Images: Amputated legs } \\
\text { Objects: None } \\
\text { Gesture/Facial expression: nurse's compassionate and sad } \\
\text { look. }\end{array}$ \\
\hline $\begin{array}{l}\text { Concluding scene: Nurse's son picks up cigarette } \\
\text { packet and puts it inside his pocket when he sees his } \\
\text { mother (nurse) approaching him. }\end{array}$ & $\begin{array}{l}\text { Words: Mother's soulful words "Don't break my heart”. } \\
\text { Gesture/Facial expression: Boy disposes the cigarette } \\
\text { packet } \\
\text { Object: cigarette packet } \\
\text { Concluding Caption: Smoking causes lung cancer, mouth } \\
\text { cancer, gangrene and other fatal diseases. Smoking } \\
\text { destroys lives. }\end{array}$ \\
\hline
\end{tabular}

Table 2 is an in-depth analysis of Advertisement 1 which is on smoking. On analyzing the advertisement using the integrated approach, it is clearly shown that the advertisement does cultivate Higher Order Thinking Skills according to Bloom's Taxonomy (1990). Not only do the 3 independent scenes give knowledge and comprehension to the audience as to the outcome of smoking on man's health, they also cultivate the audience's Higher Order Thinking Skills of analysis, synthesis and evaluation. The affective domain is also touched on by the scenes. Audience who have watched all the three scenes are not only observing and getting an understanding of the implications of the sufferings experienced by the 3 patients but are also able to analyse, synthesise and evaluate the significance of the sufferings on the family members. For instance, in the $1^{\text {st }}$ scene, the husband's remorseful repetitive phrases, "forgive me" and "forgive daddy" have both denotative and connotative meanings. What awakens the Higher Order Thinking Skills of the audience is that we are given a pitiful insight as to the bleak future ahead for we can foresee the unborn child having to grow without a father. According to Moerdyk (2013), frequency and repetition are two key elements of all advertising. Further, the images that are projected in the advertisement such as the process of amputation and the portrayal of the husband having breathing difficulty would evoke the affective domain of the audience where their emotions would be drawn out to not only emphatise with the patient but also with the wife and the unborn child. The understanding look that the nurse shares with the patient's wife further draws audience's Higher Order Thinking Skills.

In the second scene, what captures the attention of the audience would be the image of the mother's face where there is focus on the mouth with severe gangrene. Here, the audience becomes aware and they gain knowledge and have an understanding on the side effects of smoking. These are considered to be the lower order thinking skills in Bloom's 
Taxonomy. However, the son turning away from the mother would capture the Higher Order Thinking Skills of the audience whereby they would be able to empathise with the mother's condition of being rejected by the son. The audience would start thinking of how painful that moment would have been for the mother and probably would evaluate the pros and cons attached to the son's behavior. In order to justify the action, they would synthesise all other relevant and possible issues which could have led to the son's state of mind at that moment.

In the third scene, the Higher Order Thinking Skills of the audience would have definitely been cultivated through both the words and the images. The heartfelt cry "My leg is gone... all is gone" and the wife's response "yes....but you are alive. We are lucky" would make the audience analyse, synthesise and evaluate not only on the implications of smoking which would have been heightened by the image of the amputated leg, but also to imagine whether it is worth living in the condition that the victim is in. The focus would have been in defining what "we are lucky" actually means in reality. Here is where the skills of analyzing and evaluating come into play.

The concluding scene is what would have touched the audience most. The scenes in the hospital were not observed by the nurse's son. However, the emotional state and the soulful cry of the nurse to the son "Don't break my heart" is what would have drawn the Higher Order Thinking Skills of the audience. They would emphatise with the nurse who goes home with a heavy heart, having observed the three scenes. The son's immediate response seen in his action of disposing the cigarette packet would enable the audience to understand the bond between the boy and the mother and would indirectly awaken their evaluative skills and encourage smokers to quit smoking having seen how it would affect the loved ones around them. Here, the analytical skill of the boy is evoked and audience is likely to emulate it. However, it must be noted here that the effectiveness of subliminal messages are still being researched by experts but recent findings show that subliminal stimuli only cause short-term impacts on the behaviour of an individual (O'Neill, 2011).

Table 3: Analysis of Advertisement 2 (AIDS)

\begin{tabular}{|c|c|}
\hline Content Analysis & Semiotic Analysis \\
\hline $\begin{array}{l}\text { An announcement to encourage the HIV test. } \\
\text { Groups comprising of various ages group and } \\
\text { genders are shown walking through a closed } \\
\text { door which opens with streams of light shining on } \\
\text { them. } \\
\text { Subsequent scene depicts people walking } \\
\text { outside in the bright daylight. } \\
\text { Scene depicting clubbing activities including } \\
\text { sexual encounters and drug taking } \\
\text { Pregnant woman looking at mittens } \\
\text { Hospital scene with doctor, nurses as well lab } \\
\text { technician carrying out tests } \\
\text { Ends with a happy family with a newborn baby }\end{array}$ & $\begin{array}{l}\text { Words: -Background narratives- "There are a growing number of } \\
\text { unfortunate ones, who may unknowingly have contracted the HIV virus. } \\
\text { The number is increasing and you may be one of them. The only way to } \\
\text { find out is to take the HIV test because you want to be in control of your } \\
\text { life, considerate of others. Your unhealthy lifestyles may have put you at } \\
\text { risk or might bring you into contact with carriers when you have sex or if } \\
\text { you inject drugs. Perhaps you want to get married and start your own } \\
\text { family. This simple test is available at any government hospital or health } \\
\text { clinic and the results are treated in the strictest confidence. Care for } \\
\text { yourself. Care for others. Get the HIV test today". } \\
\text { Images: Clubbing scene with connotations of free sex and drug abuse } \\
\text { Objects: syringe and mittens, file cabinet } \\
\text { Gesture/Facial expression: None } \\
\text { Concluding caption: Care for yourself and care for the others. Take the } \\
\text { HIV test today. }\end{array}$ \\
\hline
\end{tabular}

Table 3 is the analysis of advertisement 2 which is on AIDS. The advertisement actually employs a narrative strategy where there is a background voice conveying the message while the scenes are being projected. The audience are shown a series of scenes which are linked in a subtle manner. First, we see a group of people of various ages and genders walking towards a closed door which opens and streams of light come shining on them which symbolically would make the audience relate the scene to the concept of enlightenment. This is where the Higher Order Thinking Skills of analysis, synthesis and evaluation are cultivated. The audience is not only given the knowledge, understanding and application as to how important taking the HIV test is but also to realise that the implications extends beyond them to the ones around them. This is illustrated by the subsequent scenes of clubbing, taking drugs and sexual encounters. The narrator's words "Your unhealthy lifestyles may have put you at risk or might bring you into contact with carriers when you have sex or if you inject drugs" and the images of the clubbing scene, free sex and drug abuse illustrates this. Further, the words "Care for yourself. Care for others" would make the audience not only understand but also to evaluate the significance of all these unhealthy habits. The repetition of the word "care" emphasises this. The message also focuses on the confidentiality issues which are shown symbolically through the lab technician's act of locking the file cabinet. The last scene which depicts a happy family with a newborn baby kind of summarises the message of the whole advertisement where the audience is given an overall conclusion on the significance of taking the HIV test to ensure a healthy lifestyle. The final scene showing a happy family is in line with what Savard and Gallagher (2012) have pointed out where they claim that advertisements that carry aspiration in their message instead of exaggeration are more powerful.

Table 4: Analysis of Advertisement 3 (Bribery)

\begin{tabular}{|l|l|}
\hline Content Analysis & Semiotic Analysis \\
\hline $\begin{array}{l}\text { Mother calling out to children to come for the breaking } \\
\text { of fast. (Malay family) }\end{array}$ & $\begin{array}{l}\text { Words: Innocent exclamation by son "Aaah, there is so much } \\
\text { of food!" and the sister's innocent utterance "Of course, our }\end{array}$ \\
\hline
\end{tabular}




\section{Children run towards the house holding hands}

Father in a thoughtful condition while contemplating food on the table

Daughter innocently stretches out her hand to hold her father's hand in as a response to his sad look

\author{
father has a lot of money". \\ Images: Variety of delicacies on the table and father's solemn \\ look \\ Object: house and food \\ Gesture/Facial expression: daughter reaching out to hold \\ father's hand \\ Concluding Caption: Break the fast with a proper source of \\ income.
}

Table 4 is the analysis of advertisement 3 which is on bribery. The advertisement conveys the message about the negative effects of bribery through just one short scene comprising of a family; mother, father and two children. The scene takes place in the dining room of a double-story terrace house. It is dinner time during the fasting month of Ramadhan. What is interesting about this advertisement is that the in-depth analysis reveals that the message had not been conveyed as clearly as the other advertisements discussed in this paper. However, the lack of directness in the message conveyed, actually acts positively on the audience as they have to interpret the nuances of the characters' interactions. This calls for the application of the Higher Order Thinking Skills of the audience. They have to analyse and evaluate why the utterances of the son and the daughter "Aaah, there is so much of food!" and "Of course, our father has a lot of money" respectively causes the father to go into a contemplative and thoughtful mood. At that point, the audience has not been given any insight into the significance of the message which is on bribery. As such, the daughter's gesture of reaching out to hold the father's hand would create an ambiguity in inference. It is only the concluding caption which draws the attention of the audience to the significance of the advertisement, 'Break the fast with a proper source of income'. The researchers were at consensus that this advertisement was not as effective as the advertisements on AIDS and Smoking. This finding is confirmed by the responses of the respondents with regards to the survey on the effectiveness of the advertisement. The advertisement would have been more effective if creative elements were added because by adding creativity to the mix and delivering short, concise and catchy messages to the audience, adverts are capable of leaving long lasting impressions on its audience (Hollis, 2011).

\section{Table 5: Analysis of Advertisement 4 (Don't Drink and Drive)}

\begin{tabular}{|l|l|}
\hline Content Analysis & Semiotic Analysis \\
\hline $\begin{array}{l}\text { Message is on the implication of driving under the influence } \\
\text { of alcohol. }\end{array}$ & $\begin{array}{l}\text { Words : Background narrator's comments about how } \\
\text { drinking under the influence of alcohol does not only } \\
\text { affect the driver but also innocent people; the mother's } \\
\text { words, "stupid...get out...get out...get out (repetition), and } \\
\text { the softly spoken remorseful apology "I'm sorry" of the } \\
\text { young drunk driver followed by an outburst of cry. } \\
\text { Images : Victim's condition focused a lot on her difficulty } \\
\text { in breathing and crying in pain; the gruesome scene of } \\
\text { her injured leg; the portrayal of how the doctors removed } \\
\text { the bloody stained clothes. } \\
\text { Gesture/Facial expression: victim's mother crying when } \\
\text { informed about the condition of the daughter; father's } \\
\text { melancholic look; mother's attempt to attack the drunk } \\
\text { driver; drunk drivers act of smashing the wall in } \\
\text { frustration. } \\
\text { Concluding Caption: Early precautious thoughts are better } \\
\text { than regrets and remorse thoughts after the incident. } \\
\text { Value live. Avoid alcohol. }\end{array}$ \\
\hline
\end{tabular}

Table 5 is the analysis of advertisement 4 which is on "Don't drink and drive". The advertisement conveys a message about the negative implications that results from driving under the influence of alcohol. The whole scene is set in one location which is the hospital. It starts with the rushing in of the victim who was has been run over by a drunk driver to the hospital. This advertisement is the second longest advertisement of the four. In terms of effectiveness of the advertisement on the audience, the analysis using the integrated approach brought to surface a number of features that were effective in capturing the audiences' thinking skills. The words spoken by the narrator as the scene was projected is effective in cultivating Higher Order Thinking Skills besides the Lower Order Thinking Skills of knowledge, comprehension and application. The message given was not only on the direct consequences of drunk driving but it also managed to capture the affective domain and Higher Order Thinking Skills of analysis, synthesis and evaluation for the narrator emphasised a lot on how innocent people are affected drastically by the actions of drunk driving. The fact that she gives some statistic as to the number of accidents which were the results of drunk driving heightens the impact on the audience. The words that the mother throws out in frustration and anger at the drunk driver, 'Stupid...get out...get out...get out' (repetition) and the softly spoken remorseful apology 'I'm sorry' of the young drunk driver followed by his outburst of cry 
reiterates the message causing the audience to analyse, synthesise and evaluate the implications related to drunk driving. The images of the victim's condition which focused a lot on her difficulty in breathing and crying out in pain and the gruesome scene of her injured leg as well as the portrayal of how the doctors remove the bloody stained clothes can be said to be effective in evoking Higher Order Thinking Skills among the audience as the images are horrifying. The facial expression of the victim's parents and the remorseful look of the young drunk driver have been portrayed in a manner that the audience would be able to empathise with them. The striking of the wall by the young drunk driver symbolically creates a depth of meaning attached to the act of knocking down the victim for it brings to mind the significance of the proverb "to cry over spilt milk". The whole advertisement if very effective and it confirms Caldwell's (2012) view that 'advertising, in its entire multitude of formats, can be a very powerful tool as it can create mental images' in people.

\section{Rating of Advertisements}

How would you rate this advertisement on 'Drink \& Drive' in delivering its message?

How would you rate the advertisement on 'Bribery' in delivering its message?

How would you rate the advertisement on 'AIDS' in delivering its message?

How would you rate the advertisement on 'Smoking' in delivering its message?

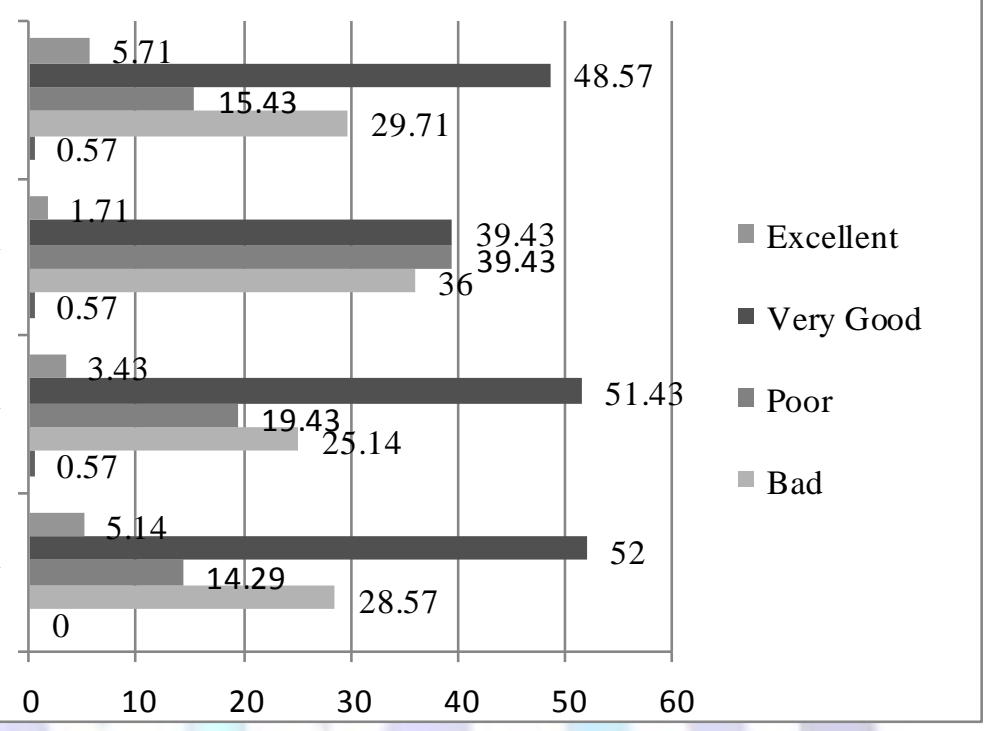

Fig 2: Ratings of Advertisements

The responses of the respondents on the effectiveness of the selected advertisements are shown in Figure 3 . The figure gives us a clear picture of what the respondents feel about the advertisement on smoking. $52 \%$ of the respondents confirmed that they thought the advertisement was 'very good' and another $5.14 \%$ said it was 'excellent'. On the other hand, $28.57 \%$ said that they felt it was 'bad' and $14.29 \%$ felt it was 'poor'. The findings clearly indicates that the audience were moved by the advertisement and their thinking skills had been cultivated especially Higher Order Thinking Skills for $57.14 \%$ felt that the advertisement was effective (responses are the total of those who found it good and excellent). With regards to how the respondents rate the advertisement on AIDS in delivering its message, nearly $51.43 \%$ felt it was very good watching the advertisement and this give us an overview that the advertisement had a positive impact on them. About $3.43 \%$ said that the advertisement was 'excellent'. $25.14 \%$ said that it was 'bad' and about $19.43 \%$ said the advertisement was 'poor' and did not do much to improve their behaviour and capture their emotions. It can be concluded on the whole that this advertisement managed to capture the interest of the audience for $54.86 \%$ of the respondents found it to be either 'good' or 'excellent'. In analyzing the advertisement on bribery, it was evident that $39.43 \%$ of the respondents felt the advertisement was 'very good' while $36 \%$ thought it was 'bad' in delivering its message. Another $22.29 \%$ felt it was 'poor'. However, $1.71 \%$ felt the advertisement was 'excellent'. It can be concluded that $58.86 \%$ responded that it was not effective (total of responses who claimed that it was 'bad or poor'). This is consistent with the finding from the document analysis as the researchers were at consensus that the advertisement was not very effective because it was very vague and lacked depth. Further, when the respondents were asked how they would rate the advertisement 'Don't drink and drive in delivering its message' nearly half, about $48.57 \%$ thought the advertisement was 'very good, $29.71 \%$ felt it was 'bad', $15.43 \%$ felt it was 'poor' and only $5.71 \%$ felt it was 'excellent'. It can be concluded that this advertisement is effective because $54.27 \%$ of the respondents agreed that the advertisement was either 'very good' or 'excellent'.

The following is the discussion of the survey results on key issues related to government sponsored advertisements. . A crosstabulation of age group of the respondents against each survey question has been analysed and discussed.

Table 6 provides us with the crosstabulation of age group with the media which captures their attention most. It is clearly proven that television is the most influencing media rated by all the generations; Baby boomers (73.3\%), Generation $X$ $(70.7 \%)$ and Generation $Y(61.5 \%)$. The least influencing media as seen in this study is rated as print with $9.6 \%$ from Generation $Y$ and $2.4 \%$ from Generation $X$. However to the Baby boomers (6.7\%), the radio is the least influential media as compared to print (10\%). The reason could be attributed to the prevalent reading habit that still exists among Baby boomers. 
Table 6: Which media gets your attention the most (select one)?

\begin{tabular}{|c|c|c|c|c||}
\hline \multirow{2}{*}{} & \multicolumn{4}{|c||}{ Which media gets your attention the most (select } \\
& Print & Radio & $\begin{array}{c}\text { Word of } \\
\text { mouth }\end{array}$ & Television \\
\cline { 2 - 5 } & & & & \\
\hline Age Group Gen Y & $9.6 \%$ & $11.5 \%$ & $17.3 \%$ & $61.5 \%$ \\
\hline Gen X & $2.4 \%$ & $4.9 \%$ & $22.0 \%$ & $70.7 \%$ \\
\hline Baby boomers & $10.0 \%$ & $6.7 \%$ & $10.0 \%$ & $73.3 \%$ \\
\hline
\end{tabular}

Table 7 is the tabulation of the responses from the respondents on the question of their understanding as to the meaning of government sponsored advertisement. The findings indicate that $93.3 \%$ of Baby boomers, $82.9 \%$ of Generation $X$ and $57.7 \%$ of Generation $Y$ understand what government sponsored advertisements are. The interesting part of the findings is that the percentage from Generation $Y$ is low. This should be of concern for it indicates not only the negative characteristics on the part of Generation $Y$ but also the ineffectiveness of GSAs. As we are aware, most government sponsored advertisements deal with social issues that are usually related to Generation $X$ and $Y$ and as such, it is crucial for both these generations to take note of the messages and react accordingly. Thus, the high percentage of respondents from Generation $Y$ not having knowledge about these advertisements should be addressed by the government. One of the ways to address this issue would be by ensuring that the advertisements are designed appropriately to draw this group's attention effectively.

Table 7: Do you know what government sponsored advertisements are?

\begin{tabular}{|ll|c|c|}
\hline & \multicolumn{2}{|c|}{$\begin{array}{c}\text { Do you know what government sponsored } \\
\text { advertisements are? }\end{array}$} \\
\cline { 2 - 4 } & Gen Y & Yes & No \\
\hline Age Group & $57.7 \%$ & $42.3 \%$ \\
\cline { 2 - 4 } & Gen X & & $17.1 \%$ \\
\cline { 2 - 4 } & Baby boomers & $82.9 \%$ & $6.7 \%$ \\
\hline
\end{tabular}

Table 8 gives us an overview of how well the government sponsored advertisements have caught the attention of the different generations. $38.5 \%$ of Generation $Y$ and $46.7 \%$ of Baby Boomers felt that the government sponsored advertisements do not catch their attention. In comparison, $48.8 \%$ of Generation X could not remember if government advertisements were able to catch their attention. This generates great concern which the government should address immediately if it wants to ensure its messages gets across to the relevant generation.

Table 8: How well have the government sponsored advertisements caught your attention?

\begin{tabular}{|cc|c|c|c|c|}
\hline \multirow{2}{*}{} & & \multicolumn{3}{|c|}{ How well has the government advertisement } \\
& & & & \multicolumn{3}{c|}{ caught your attention? } & $\begin{array}{c}\text { Do not } \\
\text { remember }\end{array}$ \\
\cline { 3 - 6 } & & Very well & Not catchy & Not well & \\
\hline $\begin{array}{c}\text { Age } \\
\text { Group }\end{array}$ & Gen Y & $15.4 \%$ & $28.8 \%$ & $38.5 \%$ & $17.3 \%$ \\
\cline { 2 - 6 } & Gen X & $7.3 \%$ & $22.0 \%$ & $22.0 \%$ & $48.8 \%$ \\
\cline { 2 - 6 } & Baby boomers & & & & \\
& & $10.0 \%$ & $6.7 \%$ & $46.7 \%$ & $36.7 \%$ \\
\hline
\end{tabular}

Table 9 gives the responses of the respondents as to how government sponsored advertisements impacted them. In the case of Baby boomers it was the messages (70\%) in the advertisements that drew the attention the most. This finding is similar to the responses of Generation Y $(46.2 \%)$ and Generation X $(68.3 \%)$ who also chose this option. Respondents from all three (3) generations indicated that the advertisements did not enable them to recall after some time. This clearly shows that government sponsored advertisements have not reached the level of being able to harness impact on longterm memory. 
Table 9: How do government sponsored advertisements affect you the most (select one)?

\begin{tabular}{|c|c|c|c|c|c|}
\hline & \multicolumn{4}{|c|}{ How do government sponsored advertisements affect you the most (select one)? } \\
\hline & & Recall & Interest & Positive impression & Message \\
\hline \multirow[t]{3}{*}{ Age Group } & Gen Y & $16.3 \%$ & $19.2 \%$ & $18.3 \%$ & $46.2 \%$ \\
\hline & Gen X & $4.9 \%$ & $4.9 \%$ & $22.0 \%$ & $68.3 \%$ \\
\hline & Baby boomers & $3.3 \%$ & $6.7 \%$ & $20.0 \%$ & $70.0 \%$ \\
\hline
\end{tabular}

Table 10 shows the responses of the respondents on which form of government sponsored advertisements that have greater impact on them. The choices provided were printed words, words with visuals, words with sounds, a moving action oriented advertisement or picture depicting a scene/story. The findings revealed that the respondents from Baby boomers $(50 \%)$ and Generation X (34.1\%) rated he 'option' words with sound'. However the findings were not consistent with the ratings from the respondents of Generation $Y(41.3 \%)$, who rated the option 'moving action oriented advertisement' as the form which created a greater impact on them. The difference in the findings between Generation $Y$ and the other two (2) generations could be attributed to the nature of youngsters today who are constantly in pursuit of active lifestyle. Hence, 'moving action oriented advertisement' would definitely have a greater impact on them.

Table 10: Which form of government advertisements creates a greater impact on you? (select one)

\begin{tabular}{|c|c|c|c|c|c|c|}
\hline & & \multicolumn{5}{|c|}{$\begin{array}{l}\text { Which form of government advertisements creates a greater impact } \\
\text { on you the most (select one)? }\end{array}$} \\
\hline & & $\begin{array}{l}\text { Just the } \\
\text { printed } \\
\text { words }\end{array}$ & $\begin{array}{l}\text { Words with } \\
\text { visual }\end{array}$ & $\begin{array}{l}\text { Words with } \\
\text { sound }\end{array}$ & $\begin{array}{c}\text { A moving } \\
\text { action } \\
\text { oriented } \\
\text { advertisement }\end{array}$ & $\begin{array}{c}\text { Picture } \\
\text { depicting a } \\
\text { scene/story }\end{array}$ \\
\hline \multirow[t]{3}{*}{ Age Group } & Gen Y & $4.8 \%$ & $15.4 \%$ & $9.6 \%$ & $41.3 \%$ & $28.8 \%$ \\
\hline & Gen X & $14.6 \%$ & $17.1 \%$ & $34.1 \%$ & $19.5 \%$ & $14.6 \%$ \\
\hline & $\begin{array}{c}\text { Baby } \\
\text { boomers }\end{array}$ & $23.3 \%$ & $10.0 \%$ & $50.0 \%$ & $6.7 \%$ & $10.0 \%$ \\
\hline
\end{tabular}

Table 11 gives the responses of the respondents as to the advertisements' duration of impact on them. The findings show that respondents from all three (3) generations; Baby boomers (48\%), Generation X (53.7\%) and Generation Y (41.3\%) claimed that the impact only lasts for few hours. It is crucial to note that very low percentages of respondents from all three (3) generations claim that the impact last more than a month.

Table 11: How long does the impact of an advertisement last on you?

\begin{tabular}{|cc|c|c|c|c|c|}
\hline \multirow{2}{*}{} & \multicolumn{3}{|c|}{ How long does the impact of an advertisement last on you? } \\
\cline { 2 - 7 } & $\begin{array}{c}\text { Few } \\
\text { hours }\end{array}$ & $\begin{array}{c}\text { One } \\
\text { week }\end{array}$ & One Day & $\begin{array}{c}\text { More than a } \\
\text { month }\end{array}$ & $\begin{array}{c}\text { One } \\
\text { Month }\end{array}$ \\
\hline Age Group & Gen Y & $41.3 \%$ & $24.0 \%$ & $17.3 \%$ & $12.5 \%$ & $4.8 \%$ \\
\cline { 2 - 7 } & Gen X & $53.7 \%$ & $22.0 \%$ & $7.3 \%$ & $7.3 \%$ & $9.8 \%$ \\
\cline { 2 - 7 } & & $63.3 \%$ & $20.0 \%$ & $10.0 \%$ & $6.7 \%$ & $.0 \%$ \\
\hline
\end{tabular}

Table 12 gives the responses of the respondents on the aspect of television advertisements which are most important to them. The options given were models, themes, background, punch line, caption and photography. The findings indicated that both Generation X (48.8\%) and Baby boomers $83.3 \%)$ rated 'caption' as the most important aspect of television advertisements. In contrast, Generation $Y(29.8 \%)$ rated 'themes' as the most important aspect. The findings for this question were surprising to the researchers for they did not expect Generation $Y$ to choose 'themes' as the most important aspect. It is known that the television advertising was initially an experimental medium for most organization and it is a struggle to develop the strategy to reach the consumers effectively at the right time. Mostly the advertisements have some of the aspects listed in Table 12 to attract consumers and to create the awareness of the importance of the subject matter. The commercial advertisers are seeking to increase consumptions of the products or services via 'branding' that mainly involves impinging the product name or image and its qualities in the minds of the consumer. However in terms of non- 
commercial advertisers, the focus is on modes of persuasion to create public awareness as a public service announcement. The findings of this research support this clearly as it is the 'caption' or 'themes' that have drawn the attention of the audience.

Table 12: Which aspect of television advertisements is most important to you? (select one)

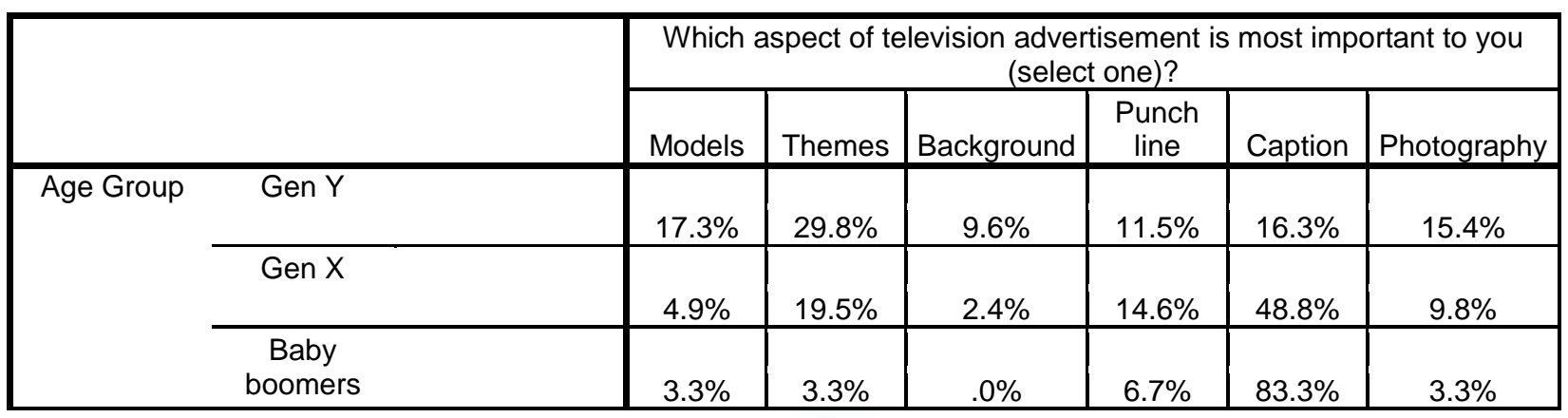

Table 13 gives the cross-tabulation of age group with the question as to how emotionally they are impacted by the government sponsored advertisements. $58.7 \%$ of Generation $\mathrm{Y}, 78 \%$ of the Generation X and $86.7 \%$ of Baby boomers said that they were only impacted on an average level. These findings indicate that government sponsored advertisements do not have an in depth impact on the respondents immaterial of age group. Mostly consumers watch television to be entertained rather than to actively "learn" the message being delivered by the advertisement so the chance of remembering advertisement or what they have to say is generally low. Therefore, government sponsored advertisements must be more engaging so as to evoke greater mental effect and boost its likelihood of being remembered.

Table 13: How emotionally impacted are you with the government sponsored advertisements?

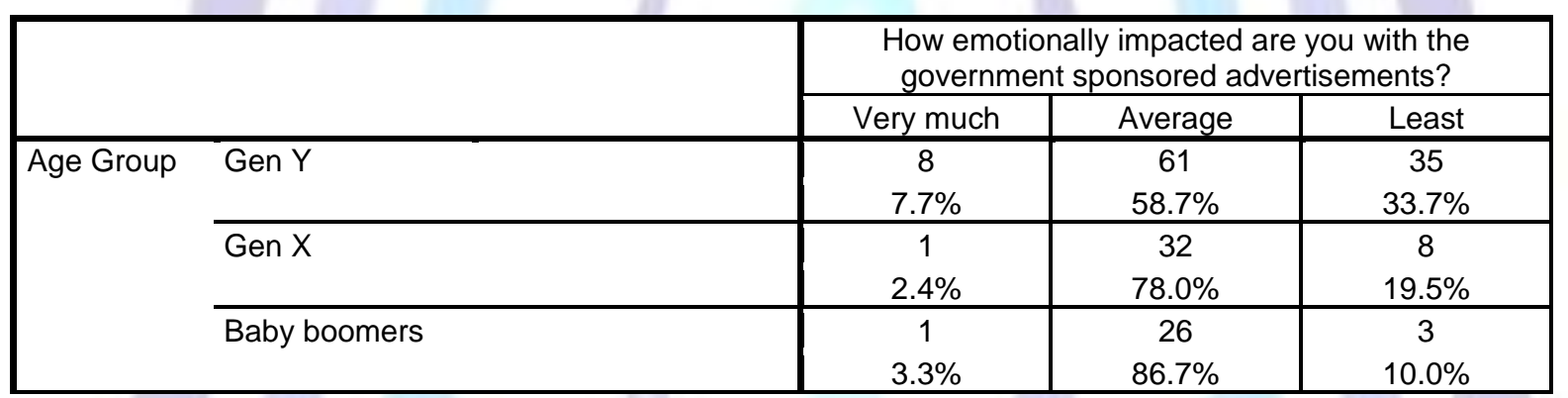

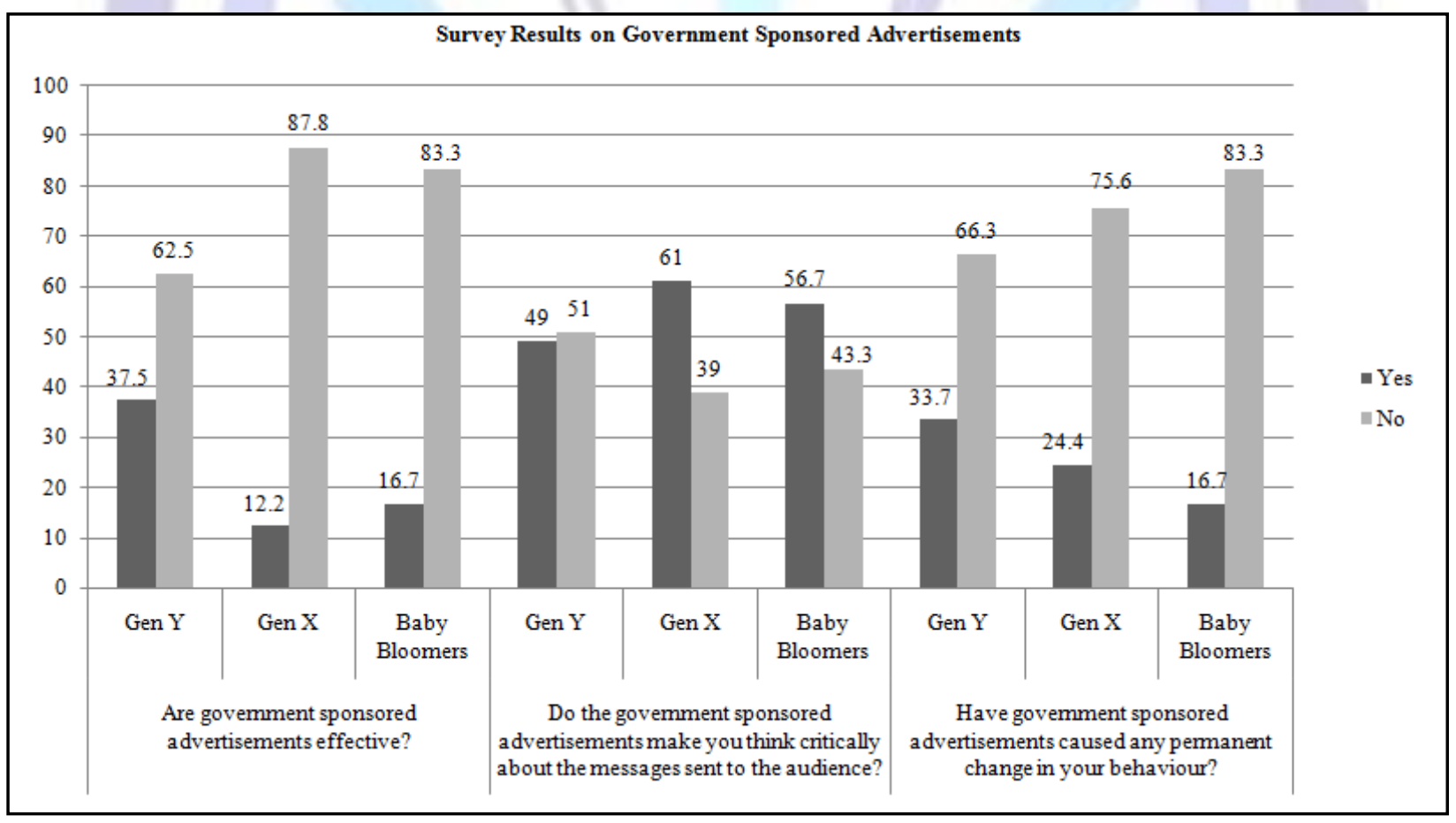

Fig 3: Evaluation of Advertisements 
Figure 3 shows the responses of the respondents with regards to the effectiveness of government sponsored advertisements. The findings indicate that $83.3 \%$ of Baby Boomers, $87.8 \%$ of Generation $X$ and $62.5 \%$ of Generation $Y$ felt that the government sponsored advertisements are ineffective and only a handful of the respondents felt otherwise. Governments and their agencies employ advertising as a key communication tool for "social marketing" of new policies, legislation, programs or projects to the community. However it is of concern that the study indicates that more than $60 \%$ of respondents from the various age groups have responded saying that the advertisements are ineffective. With regards to whether government sponsored advertisements make the respondents think critically about the messages broadcasted, the responses indicate that almost half of Generation $Y(49 \%)$ felt that the government sponsored advertisements did not make them think critically about the messages broadcasted. However, the respondents from Generation $X(61.0 \%)$ and Baby boomers (56.7\%) confirmed that the advertisements made them think critically about the messages. The findings indicate that the advertisements failed to draw the Higher Order Thinking Skills of Generation Y. In relation to the question of whether government sponsored advertisements caused any permanent behavioral changes in them, the findings indicated firmly that respondents from all three (3) generations did not undergo any permanent changes as the advertisements did not have much impact on them. A majority of Baby boomers $(83.3 \%)$, Generation $X(75.6 \%)$ and Generation $\mathrm{Y}(66.3 \%)$ answered 'No' to this question.

\section{CONCLUSION AND FUTURE RECOMMENDATION}

The findings of the qualitative research method where four (4) government sponsored advertisements were analysed using an integrated approach (Content and Semiotic Analysis) revealed that the advertisements do inculcate Higher Order Thinking Skills (HOTS) of analysis, synthesis and evaluation according to the adapted Bloom's Taxonomy. In addition, it was also proven that the advertisements did tap on the affective domain of audience. The findings from the survey supported the findings of the document analysis in that the respondents were affected by government sponsored advertisements as a whole. One aspect of the findings that need to be addressed is that in the survey, respondents from Generation $Y$ generally responded with responses that indicated government sponsored advertisements had a lesser impact on them. As such, it is crucial for government bodies in charge of conveying messages to the general public to take note of this and ensure all future advertisements are designed to cater not only to Higher Order Thinking Skills but also to draw the attention of audience from Generation $Y$ as most social issues of concern currently are those dealing with Generation $X$ and $Y$. Thus, government advertisements need to to create and enhance positive impact on the audience. It is important to embark on a strategy that is carefully developed by considering the tone and balance active engagement between positive and negative consequences. A more balanced tone of engagement would deliver better impact and evoke a more positive response. This is crucial because government sponsored advertisements are designed to ensure public welfare and social development where the objective is to transmit messages intended to change attitudes and behavior to benefit the public at large.

\section{REFERENCES}

[1] Anderson, P., Brujin, A; Angus, K, Gordon, R \& Hastings, G; (2009). Special Issue: The Message and the Media Impact of Alcohol Advertising and Media Exposure on Adolescent Alcohol Use: A Systematic Review of Longitudinal Studies. Alcohol \& Alcoholism Vol. 44, No. 3, pp. 229-243.

[2] Berelson, B. (1952). Content Analysis in Communication Research. Glencoe, III: Free Press

[3] Bloom, B. S. (Ed.). (1956). Taxonomy of educational objectives: Handbook 1: Cognitive and Domain. New York: Mc Kay.

[4] Caldwell, M. (2012). Power of advertising in full display. Available http://www.irontontribune.com/2012/11/25/power-of-advertising-on-full-display/ [Accessed 3 Jun 2013].

[5] Culler, Jonathan. (1986). Ferdinand de Saussure (rev. ed.). Ithaca, NY: Cornell University Press.

[6] Curtis,

$$
\text { A.(2011) What is advertising. Available }
$$

http://www.uncp.edu/home/acurtis/Courses/ResourcesForCourses/Advertising/AdvertisingWhatlslt.html 22th May 2013].

[7] Devadas, A, and Manohar, H L; (2011). Shopping behavior of rural consumer migrated to urban area in the Indian context - An emerging market. Journal of Business Management Vol. 5(6), pp. 2276-2282.

[8] Glasgow University Media Group. (1980). More Bad News. London. Routledge \& Kegan Paul Guy, B.S. and Patton, W.E. (1989), "The Marketing of Altruistic Causes: Understanding Why People Help", The Journal of Consumer Marketing, 6, 1, 19-30.

[9] Hollis N. (2011) Why Good Advertising Works (Even When You Think It Doesn't). The Atlantic. 31 August. Available from: $\quad$ http://www.theatlantic.com/business/archive/2011/08/why-good-advertising-works-even-when-you-think-itdoesnt/244252/\#slide4 [Accessed 26 May 2013]

[10] Holsti, O.R (1969). Content Analysis for the Social Sciences and Humanities. Reading, MA:Addison-Wesley

[11] Krippendorff, K. (1980). Content Analysis: An Introduction to Its Methodology. Newbury Park, CA: Sage.

[12] Langrehr, D. (2003). From a semiotic perspective: inference formation and the critical comprehension of television advertising. Reading Online. Retrieved on 21 August 2012 from http://www.readingonline.org/articles/langrehr/ 
[13] Leiss, W., Stephen K. \& Sut J. (1990). Social Communication in Advertising: Persons, Products and Images of WellBeing (2nd Edn.). London: Routledge

[14] Levens, M (2012) Marketing: Defined, Explained, Applied 2nd, Pearson Education. Prentice Hall: New Jersey

[15] Long, M., \& Ross, S. (1993).Modifications that preserve language and content. In M. L. Tickoo (Ed.), Simplification: Theory and application (pp. 29-52). Singapore: SEAMEO Regional Language Center.

[16] Mayer, R., \& Goodchild, F. (1990). The critical thinker. New York: Wm. C. Brown.

[17] McDaniel, S. W. and Valerie A. Z. (1984). "The Ef-fect of Fear on Purchase Intentions," Psychology and Mar-keting, 1 (Fall/Winter), 73-82.

[18] McQuarrie, E. \& David G. M. (1999). 'Visual Rhetoric in Advertising: Text-Interpretative, Experimental and ReaderResponse Analyses', Journal of Consumer Research 26(1): 37-54

[19] Mertes, L. (1991). Thinking and writing. Middle School Journal, Vol. 22, pp.24-25

[20] Moerdyk, C. (2013) When do ads start irritating? Bizcommunity [online]. 18 February. Available from: http://www.bizcommunity.com/Article/196/12/89423.html [Accessed 6 June 2013].

[21] Mohd Helmi A R; Ros Zayanah J A Z; Fauziah Ahmad; \& Novel Lyndon; (2012). Green Advertising and Environmentally Responsible Consumer Behavior: The Level of Awareness and Perception of Malaysian. Asia Social Science. Vol. 8, No. 5; pp.46-54

[22] Morris, C. W. (1938/1970). Foundations of the Theory of Signs. Chicago: Chicago University Press

[23] National Institute of Drug Abuse (NIDA). (2001). Shows TV PSAs Effective American Journal of Public Health Research http://cannabisnews.com/news/list/NIDA.shtml retrieve on 24th August 2012.

[24] Peirce, C. S. (1931). Collected Writings (8 Vols.). (Ed. Charles Hartshorne, Paul Weiss \& Arthur W Burks). Cambridge, MA: Harvard University Press

[25] Ray, M. L. and William W. (1970). "Fear: The Potential of an Appeal Neglected by Marketing." Journal of Marketing, 34 (1), 54-62.

[26] Rosenblatt,L.M. (1978). The reader, the text, the poem. The transactional theory of literary work. Southern Illinois: Carbondale.

[27] Rosenblatt, L. M. (1985). The reader, the text, the poem: The transactional theory of literary world. Carbondale, I L: Southern Illinois University Press.

[28] Rosenblatt, L. M. (1994). The transactional theory of reading and writing. In R.B. Ruddell, M.R. Ruddell, \& H. Singer. (eds.) Theoretical modals and processes of reading. $\left(4^{\text {th }}\right.$ ed.) Newark, DE: International Reading Association. (pp. 1057-1092)

[29] Savard, L. and Gallargher, M. (2012) Aspiration vs. Exaggeration. Thoughts and Notions [blog]. Available from: http://www.blackcoffee.com/blog/2012/12/04/aspiration-vs-exaggeration/ [Accessed 6 June 2013].

[30] Spence, H. E. and Reza Moinpour. (1972). "Fear Appeals in Marketing: A Social Perspective," Journal of Marketing, 36 (July), 39-42.

[31] Sternthal, B. and C. S. Craig (1974), "Fear Appeals: Revisited and Revised," Journal of Consumer Research, 1 (3), 22-34.

[32] Sturrock, J. (1986). Structuralism. London: Paladin

[33] Suggett, P (2010). Different Types of Advertising Methods : The Major Tactics Used in Modern Advertising to Reach Consumers http://advertising.about.com/od/advertisingprojects/a/Different-Types-Of-Advertising-Methods.htm retrieved on 20th August 2012

[34] Tanner, B. H, and David R. E. (1991), "The Protec-tion Motivation Model: A Normative Model of Fear Appeals," Journal of Marketing, 55 (July), 36-45.

[35] Tanner, J. F., Jr., Ellen D. and Melvin R. C. (1989). "Pro-tection Motivation Theory: An Extension on Fear Appeals Theory in Communication," Journal of Business Research, 19, 267-76. , B.

[36] Weber, R. P. (1990). Basic Content Analysis, 2nd ed. Newbury Park: CA.

[37] Williamson, J (1978): Decoding Advertisements. London: Marion Boyars

[38] Wooden R; (1997). What makes a successful PSA campaign? http://www.psaresearch.com retrieved on 21 August 2012. 


\section{First Author's biography with Photo}

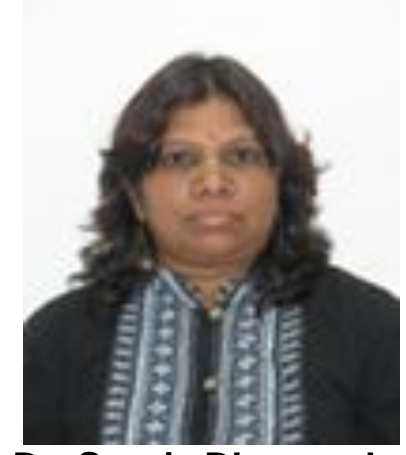

Dr. Saroja Dhanapal

Dr. Saroja Dhanapal is a veteran in the academic arena. She has contributed extensively to the academic profession as she has been teaching for the past 29 years in both public and private universities. She started her teaching profession after completing a three years teachers' training course in Seri Kota Teaching Training College, Kuala Lumpur where she obtained an A for her teaching practice. She then pursued her B.A. (Hons.) in English Literature in University of Malaya and went on to successfully complete her M.A (English Literature) in the same university. The topic of her research is "Robert Frost as a Modern Poet". In addition to this, she has also completed her L.L.B (Hons.) as an external student with the University of London and her LLM in University of Malaya. In the year 2008, she completed her PhD in TESL in University Putra Malaysia. Her research title is "Cultivating Critical and Creative Thinking Skills through an Integrated Approach to the Teaching of Literary Texts'. Among the subjects that she specializes in are English Literature, English Language, Research Methodology, Critical Thinking, Air and Space Law, Human Rights Law, Family Law and Law of Tort. She has experience in supervising both undergraduate and post graduate students. She has published books as well as articles in international journals and conference proceedings. She is currently pursuing her PhD in Human Rights Law in the University of Malaya. 